\title{
Wang Lixiong, an atypical intellectual
}

The author of the novel Huanghuo, highly critical of the Peking regime, carries on his activities inside China

\section{Rémi Quesnel}

\section{(2) OpenEdition}

\section{Journals}

Édition électronique

URL : http://journals.openedition.org/chinaperspectives/776

DOI : 10.4000/chinaperspectives.776

ISSN : 1996-4617

Éditeur

Centre d'étude français sur la Chine contemporaine

\section{Édition imprimée}

Date de publication : 1 décembre 2003

ISSN : 2070-3449

Référence électronique

Rémi Quesnel, «Wang Lixiong, an atypical intellectual », China Perspectives [En ligne], 50 | novemberdecember 2003, mis en ligne le 19 avril 2007, consulté le 28 octobre 2019. URL : http:// journals.openedition.org/chinaperspectives/776 ; DOI : 10.4000/chinaperspectives.776

Ce document a été généré automatiquement le 28 octobre 2019

(c) All rights reserved 


\section{Wang Lixiong, an atypical intellectual}

The author of the novel Huanghuo, highly critical of the Peking regime, carries on his activities inside China

\section{Rémi Quesnel}

\section{NOTE DE L'ÉDITEUR}

Translated from the French original by Michael Black

1 Wang Lixiong, author of the well-known political novel, Huanghuo (Yellow Peril), which appeared in the early 1990s, occupies a unique place in the Chinese intellectual world. He expresses himself in a way which is highly critical of the regime in Peking, while carrying on his activities inside China, rather than abroad as is the case with some dissidents. Wang Lixiong made a name for himself by writing novels, but he is also active in Chinese environmental protection circles and has produced studies of sensitive problems such as the nationalities question. He is also the webmaster of a site dedicated to what he calls "democracy by stages".

It may seem surprising that Wang Lixiong carries on his activities in mainland China. How come he is tolerated? When does someone overstep the mark? Before answering these questions, we propose an overall view of Wang Lixiong's intellectual output, which is not widely translated and is therefore little known in the West. We will attempt to define his approach and the way in which he envisages his role as an intellectual.

A diverse intellectual output

3 Wang Lixiong was born in 1953 in Changchun in Manchuria, and now lives in Peking. Sent away for re-education during the Cultural Revolution, he began to write poetry. At the end of the Cultural Revolution, after studying automobile mechanics, he worked in car factories in Manchuria and in Wuhan. He became interested in political thought early on, and formulated the idea of an "electoral system by stages" by 1975. In 1978, 
Wang participated in the Wall of Democracy movement and published his first short story in the magazine Jintian (Today). In 1980, he left the Wuhan car factory and devoted himself to literary creation as an independent. He wrote film scripts and published his first novel in 1983. In 1984 he floated down 1,200 kilometers of the Yellow River on a raft made from the inner tubes of truck tyres, passing through areas inhabited by Tibetans, which got him interested in the Tibetan question. He joined the Association of Chinese Writers in 1988, and in the same year began to write the political fiction novel Yellow Peril ${ }^{2}$, which was to be a resounding success.

4 From 1991 to 1994, he wrote a book of political theory, Rongjie quanli-Zhuceng dixuan zhi (Distribution of Power-An Electoral System by Stages), in which he took a position in favour democratic reforms in China. In 1994, Wang launched with some others a nongovernmental organisation (NGO) for the protection of the environment, Ziran zhi you (Friends of Nature) $)^{3}$. The years 1995-98 saw frequent journeys to Tibet and led to the study Tianzang: Xizang de mingyun (Celestial Funeral: The Destiny of Tibet) ${ }^{4}$. In 1999, he tried to explore the question of Xinjiang from the same point of view, and was briefly arrested. In 2001, he published Xinjiang zhuiji (Memories of Xinjiang) where he recounts his misadventures in Urumqi. Most recently, Wang had an opportunity to meet the Dalai Lama and to produce the results of fresh thoughts. In 2001, he created a sensation by resigning from the Chinese Writers Association ${ }^{5}$.

"Yellow Peril"

5 Yellow Peril, Wang Lixiong's best-known book was published by a Chinese editor in Toronto, Mirror's Books, in 1991, under the pseudonym Bao Mi (literally: kept secret). The novel was a great success in the Chinese world and was quickly published in Taiwan. It has not been published in the People's Republic, but pirate editions circulate quite widely. It is also distributed in the form of computer diskettes and is available free of charge on the Internet. The novel is in three volumes and is 1,060 pages long. It has not been translated into Western languages.

The novel's hero, Shi Ge, is an advisor to the top Chinese leaders, while the country faces enormous problems: soaring birth-rates, an energy crisis, large-scale corruption, etc. Shi Ge, aware of these difficulties, is tempted to turn away from the path of economic growth and imagines alternative solutions. In this context of crisis, the General Secretary of the Chinese Communist Party (CCP) takes some sensitive measures including a review of the legal proceedings of the events in Tian'anmen Square in 1989, and the concession of a province in Manchuria to Japan because of the enormous debt. In the face of what is perceived as weakness in the leadership, the "hard" wing of the Party, led by the military, has the General Secretary assassinated and sets up a fascistic leadership. Shi Ge is now in an alibi position but takes advantage of it to attempt an experiment in development which respects the environment. There follows the breakup of the country and civil war, with Taiwan joining the southern provinces. A nuclear war on a world scale is unleashed.

7 The author also imagines the emergence of a group which practices qigong, and is transformed into a political movement. One obviously thinks of the Falungong phenomenon. Also noticeable is the figure of the intellectual "counsellor to the prince", who returns constantly to the forefront of the story. In the Chinese context, one is tempted to speak of zhinang ${ }^{6}$. It is of course very appealing to identify Wang Lixiong with the character of Shi Ge, who is both the conscience and saviour of humanity, and is ready to collaborate with all sorts of regimes-the CCP, the fascistic military, an 
administration set up by the great foreign powers-for the salvation of the people and of humanity, beyond any short-term considerations of honour or morality.

The figure of Shi Ge, of the intellectual as hero, can make us smile, but it is what gives Yellow Peril its originality and sets it apart from entertaining "blockbuster" political fiction.

China and democracy

9 Wang Lixiong clearly favours democratic reforms in his writings. He is the originator of an "electoral system by stages". This system is set out in detail in Distribution of PowerAn Electoral System by Stages, which he considers to be his major work. In his Memories of Xinjiang, Wang tells how, when he was imprisoned and pressured to reveal his "networks" he considered giving up the idea of committing suicide, for fear of not being able to carry out his project. He nevertheless attempted it, but fortunately without success.

10 Wang Lixiong is the webmaster of a site devoted to democracy by stages. This site, which is in Chinese only, presents several hundred articles by numerous authors, in which various democratic systems are presented, and their advantages and drawbacks listed and evaluated. Some pages are reserved for forums, others for current events. Wang Lixiong's Internet site was temporarily closed by the authorities on February 25th 2002. It nevertheless reopened some time later7. Wang Lixiong gives a succinct summary of his electoral system in Memories of Xinjiang: "In the structure of an electoral system by stages, each module, each level, is autonomous, there is no group which dominates from the top to the bottom, no part crushes any other. Thus all the parts are inclined to maintain a tolerant and peaceful spirit. Moreover this structure would allow various ethnic groups to form. Within each autonomous body, none need fear interference, and conflict would have no reason to break out. Each autonomous body could follow its own principles, spread its culture and protect its members. As for the exchanges between the autonomous bodies, they would be conducted by the elected representatives of a higher level of the electoral system by stages. These high-level exchanges would be marked with reason and wisdom in compromise. And when enough time had passed, the sources of heterogeneity and separatism would dry up and society would gradually achieve a state of fusion".

Environmental protection

11 As can be seen in Yellow Peril, Wang Lixiong is particularly interested in environmental questions. His descent of the Yellow River on an inflatable raft stems also from this awareness. Wang Lixiong believes that development that does not take sufficient heed of these questions is in danger of leading to catastrophe.

In 1994, Wang Lixiong took part in the foundation of Ziran zhi you, the first Chinese environmentalist NGO. The organisation's objective is to raise the public's awareness of the need for environmental protection. It organises conferences and camps for young people, and publishes information. It also takes on selective projects, such as saving the Tibetan antelope. The organisation's website is a good point of departure for research into environmentalist circles in the People's Republic. However Wang Lixiong was forced to resign from Ziran zhi you in February 2003; it seems that his disputed personality prevented the successful working of the organisation ${ }^{8}$.

The nationalities question-the case of Tibet

13 The nationalities question has an important place in Wang Lixiong's activities. The major work he has devoted to it is Celestial Funeral: The Destiny of Tibet, a work of 600 
pages, which was published in Hong Kong in 1998 and is also available on the Internet. The book is the fruit of ten journeys to Tibet, and a total of more than two years spent living there between 1995 and 1998.

The work has not been published, but one can find various sources on the Internet which present its contents'. Wang's starting point is the recognition that books about the Tibetan question generally take the point of view either of Peking or of Dharamsala, which favours neither dialogue nor the search for a compromise. He therefore seeks a middle way. His thesis is that Peking refuses dialogue with the Dalai Lama for two reasons: both parties have different geographical conceptions of Tibet, which spills over into other Chinese provinces, and Peking cannot tolerate any form of political organisation which escapes it. Yet the Dalai Lama's demands no longer have any grounds, beyond these two points in the Chinese view. So the situation is one of stalemate. As Wang sees it, Peking holds the cards, but the strong are rarely inclined to make concessions. As for the Dalai Lama, the spiritual nature of his power leaves him little margin for manœuvre on the political level.

In the wake of Celestial Funeral, Wang was invited to Dharamsala by the Dalai Lama. He did not go, but finally met him in the United States, and in April 2002 published Yu Dalai Lama duihua (Conversations with the Dalai Lama).

In an article which was partly published in translation in the literary supplement of Courrier International ${ }^{10}$ last year, Wang explained the successive stages of Chinese policy in Tibet: the United Front (preservation of the social and religious system) in the 1950s, then collectivisation and class struggle in the 1960s, until the end of the Cultural Revolution. This second stage put Tibet in tune with the rest of China, and Wang emphasises the violence of the destruction of the monasteries by the Tibetans themselves, which he explains as religious fervour, with Mao being a sort of God. Finally, since the era of Deng Xiaoping and the end of Maoist ideology, a return to traditional religion has served to fill the void. This return of the religious is of course favourable to the Dalai Lama, who is the supreme spiritual authority and the international symbol of Tibetan identity. As Wang sees it, this policy has improved the living conditions of Tibetans but has cost the CCP its legitimacy on the high plateaus. Therefore new solutions need to be found.

The question of Xinjiang

17 Memories of Xinjiang was written between February and April 2001, in Peking. Wang Lixiong tells of his journey to Xinjiang in early 1999. The text is available on the Internet ${ }^{11}$ and when printed out comes to fifty-one A4 pages. The first part recounts the events of Wang Lixiong's journey: approaches, arrest, interrogations, sufferings, prison, etc. The second part is devoted to a analysis of the situation in Xinjiang: Wang identifies the problems and tries to imagine a solution. Lastly, the third part of the book contains Wang's reflections on the way in which he conceives his role as an intellectual.

18 The events which make up the first part of the narrative can be summarised fairly succinctly. Wang went to Urumqi to make contacts and collect documents in order to write a book on Xinjiang along the lines of Celestial Funeral. In order to do this, he photocopied an internal Party publication about the Xinjiang Production and Construction Corps, which was classified "Secret". As he was leaving Xinjiang, with the intention of returning there the following summer, he was arrested, accused of stealing state secrets, and interrogated at length. Under pressure to betray his alleged network, 
he attempted suicide by severing his carotid artery. After being hospitalised, he was imprisoned for several weeks in a detention centre of the Ministry of Security. There he was able to mix with Uyghur political prisoners with whom he shared a cell, and these circumstances allowed him to develop his thinking on the question of Xinjiang. Finally, Wang was mysteriously set free, in exchange for a written promise to help the state if it became necessary. On his return to Peking, Wang was overcome with regret and considered this signature to be a betrayal of his own conscience. He therefore wrote to renege on his written promise and waited to be rearrested. When this move went unanswered, he wrote Memories of Xinjiang in order to make a confession to his readers and to prove that he did not have any "protection" in high places.

Peking's policy in Xinjiang

19 Wang Lixiong broaches the question of Xinjiang in the second part of the book. He begins with the observation that the native population on the one hand, and the Han on the other, make up, in the single territory of Xinjiang, two distinct and increasingly antagonistic communities. He attributes all this to three aspects of Peking's policy: security, economics and ideology. The analysis of the problem focuses on the government's policy, which is the only source of action and power. Is Wang Lixiong addressing the government? Wang has often emphasised the autocratic dimension of Chinese government, so it is only half surprising that all criticisms are aimed at it.

On the level of security policy, Wang Lixiong draws parallels between current notions and those of the 1960s. In those days the danger was "Soviet revisionism". Nowadays it is "separatist forces" as well as "illegal religious movements". The fundamental difference is that the danger, previously of external origin, is now internal. The result of this policy is to make the native populations of Xinjiang subject to surveillance and to make the Han in Xinjiang their guards. Wang also contrasts the 1960s-during which the class struggle relegated ethnic antagonisms to the background-with the present. He believes that the government's hard political line can only make it unpopular, all the more so as the religious antagonisms between the inhabitants of Xinjiang and the Han are sharper than those between the Han and the Tibetans. Wang is of the opinion that in the long term, the CCP's present policy can only lead to an intensification of these antagonisms, and produce serious crises such as those in the Middle East or in Chechnya.

21 Wang Lixiong explains the Xinjiang Production and Construction Corps ${ }^{12}$, in which he sees a source of antagonism between the two communities. He follows this up with an analysis of Peking's economic policy in Xinjiang, of which the key element is the government's programme to develop the West ${ }^{13}$. In this way, in Wang's analysis, the government hopes to reduce the differences in wealth. Next, economic development is supposed to go hand in hand with a certain secularisation of society. Lastly, Wang underlines the increase in subsidies granted to Xinjiang by Peking during the 1990s, making Xinjiang the most generously endowed region in the whole country. Despite these efforts and the genuine improvement in living standards in Xinjiang in the last few years, in Wang Lixiong's eyes this economic policy does not contribute to bringing the two communities together. On the contrary, Wang observes that this economic programme is more beneficial to the Han who have settled in Xinjiang, who are often more educated, and thus more competitive, and linguistically advantaged for all the administrative and technical professions. The natives carry out the most unpleasant jobs. Thus, to the divisions between the communities because of differences of identity 
and culture, are added the increasing disparities in wealth. Only a small influential minority of Uyghurs, Kazakhs and others benefit from this economic policy, all the more so as problems of corruption tend to aggravate the inequalities, adds Wang Lixiong.

After the security and economic policies, Wang Lixiong comments on Peking's ideology, and especially nationalism ${ }^{14}$. In his opinion, ethnic oppression has appeared in Xinjiang in the last ten years, whereas, before, all were subject to the same political oppression. Wang believes that nationalistic propaganda can only give the native populations the feeling of being subjected to an ethnic oppression which is difficult to remedy by political means. On the contrary, if the quarrel between the various populations reaches the point of no return, political reforms are more likely to lead the native populations to take advantage of the transition situation to achieve independence. Thus the nationalist ideological policy hampers any attempt at political reform in China. Wang Lixiong points out that nationalism is a double-edged sword for the Chinese government. In the case of China, those who do not identify with the concept of a "Chinese nation" will be easily tempted to turn nationalist discourse around in favour of their separatist demands.

Wang Lixiong compares the CCP's policy to an acrobatic performance which is reaching its outer limit and warns against the consequences of a fall. He finishes by criticising the clumsiness of the CCP's technocrats, who are not sufficiently inspired by the "humanist spirit" ${ }^{15}$, which to him is essential in order to take on questions as sensitive as that of Xinjiang.

The search for a solution

Where solutions are concerned, Wang Lixiong provides some broad outlines. He lists some preliminary conditions, the traps to be avoided, and explains what should not be done. But he does not offer any concrete plan of action, nor any miraculous political solutions. His approach consists of defining the problems. It would be more accurate to speak in terms of a propitious state of mind than of solutions.

Wang Lixiong recounts his simulated "negotiations" with the Uyghur political prisoners who were his cellmates, and served as "representatives" for the occasion. A number of ideas appear, jumbled together; to Wang, speaking of these negotiations is an opportunity to list the paths to be avoided. He dismisses extremist solutions and any resort to terrorism by the populations of Xinjiang, which can only make the problems worse. He ventures a comparison with the situation in Tibet. According to him, the pacifist behaviour of the Tibetans has won the sympathy of the young educated Han; Chinese bookshops abound in publications on Tibet and some young Chinese even convert to Lamaism. Mention of Xinjiang, on the other hand, evokes more fear than sympathy.

The other path to be avoided is that of nationalism ${ }^{16}$ which, to Wang Lixiong, is nothing but a travesty of Han nationalism, which is experienced as a form of exclusion by part of the population of Xinjiang. Wang suggests maintaining a certain distance from the concepts of "nation" and "state". Finally, Wang and his cellmates agree on the fact that the independence of Xinjiang is inconceivable. Their argument is that $40 \%$ of the population of Xinjiang is Han, and that even without military intervention by Peking, they would be able to defend themselves by force.

In contrast with the problems, which rest on the shoulders of the government, Wang addresses the solutions to everyone, and particularly to the inhabitants of Xinjiang. 
While it is difficult to influence the security and economic policies of the government, everyone can cast a critical eye on ideological propaganda. This sheds a new light on Wang Lixiong's work: not all solutions necessarily come from on high, and each person can act at their own level.

Wang Lixiong concludes that the only possible solution is real autonomy. At the moment, Xinjiang is an autonomous province, but its cadres are appointed by Peking. Xinjiang is in a situation of chronic financial dependence on the central government, and this administrative structure paralyses any local initiative. As Wang sees it, real autonomy would be beneficial to both parties. At present, the government is criticised no matter what it does. The best solution is to devolve responsibility to the local population, who are best able to know their own needs. The question of natural resources must obviously give rise to a preliminary agreement, as should compensation for the regions concerned. Wang wonders how to incorporate the Han in Xinjiang into the framework of regional autonomy. He seizes the opportunity to propose his "electoral system by stages". The starting point of his thought is that the existing political systems are not able to provide a solution to the problems of Xinjiang. So he agrees with his cellmates that an entirely new solution must be envisaged. They seem to welcome the system which Wang favours.

Wang Lixiong's approach is to reject ready-made solutions and try to come up with a new one. Of course, this may seem very vague, even naïve and Utopian, and far from being entirely novel, it is reminiscent of certain federalist systems. But Wang Lixiong's solution is paradoxically redeemed by its vagueness, which guarantees the absence of solutions which conform to any sort of orthodoxy, and the way is left open to reflection. In his defence, one might also add that in publishing Memories of Xinjiang, he was pursuing another objective, related to his arrest. Wang analyses the relations between the Han and the Uyghurs and the weaknesses of Peking's policy, which in China is already a considerable step.

Intentions and methods

Wang spells out his intentions at the beginning of Memories of Xinjiang. On the one hand it is a question of summarising his misfortunes and informing his readers about what really happened. Wang seeks to convince his readers that he has not "sold out" to the government. More generally he also gives his reasons for being interested in the question of nationalities. By his own admission, the prophetic aspects of Yellow Peril frighten him. To avoid such extremes, the problem of the nationalities needs to be resolved in a timely fashion, for its solution is the precondition to any political reform. It must also be said that the dangers of separatism are frequently invoked to postpone reforms.

31 In Memories of Xinjiang, Wang Lixiong writes that he has given up fiction in order to devote himself to studying problems in the field. This is the context of his journey to Urumqi. Wang explains that he left for Xinjiang at the instigation of a certain $Q$, who directs a research centre which is, in his own terms, "outside the system". $Q$ suggests that he carry out research along the same lines as produced Celestial Funeral, and finances his journey. Wang does not reveal the identity of $Q$ or of his organisation.

Wang sets out to establish links with the inhabitants of Xinjiang, both Han and native. He is accompanied by a friend from the Hui minority, who does not participate in the research. Wang also seeks to obtain documents on the situation in Xinjiang, but many of the key documents are internal to the CCP and are not easy to obtain. Wang devotes 
a whole paragraph to the problem of his "status", of his "quality" (shenfen) as a researcher. Since he has no references from an official research institute, it is difficult for him to gain access to influential circles. In order to overcome this difficulty, Wang Lixiong produces his membership card of the Chinese Writers Association. Wang's research project is blocked by his arrest; however he then has an unexpected opportunity to rub shoulders with Uyghur political prisoners in his cell and takes advantage of this to approach them, question them and debate with them.

The question of status is important: Wang Lixiong is not a professional researcher. Nowadays, the Chinese intelligentsia is for the most part professionalised. Those who write in intellectual journals such as Dushu (Reading) and Ershiyi shiji (21 ${ }^{\text {st }}$ Century) are usually professors or researchers, in mainland China or abroad. This is not the case with Wang Lixiong.

In the last few chapters, Wang Lixiong begins to think about the impact of his wanderings in Xinjiang. The reasons for his sudden release remain unclear, even though he mentions several possibilities. First of all, news of his arrest was believed to have caused a wave of indignation abroad, and Peking is careful to protect its reputation. It turns out also that his mother and stepfather wrote to Jiang Zemin; Wang Lixiong's father was once Jiang Zemin's superior in an car factory in Changchun ${ }^{17}$.

Wang finds two things unbearable: the idea that the public might think that his release was due to "protection" inside the political apparatus; and his written promise to collaborate with the government if necessary, which left him with the impression of having been freed in order to become a lackey. So he decides to take back his promise in writing, even if it means returning to prison. He writes a letter first to Jiang Zemin, and when this remains unanswered, he writes a second one to the Office of Security in Urumqi, which also produces no answer and has no consequences. His written promise makes him despair, for it seems administratively irrevocable, and he thinks that it will forever cut him off from the government: if the government consulted him, he would have the impression of answering on the basis of this promise which was made under constraint, and he would be forced to refuse.

In this context, Wang mentions the Falungong affair, during which he was discreetly consulted by a security officer who promised to relay his opinion to the top through rapid channels. Wang Lixiong explains that he refused to express his opinion because he felt bound by the famous letter. And yet he is convinced that no collaboration with the government should be taboo, as long as it is freely given, and regrets that he was unable to contribute, however modestly, to the resolution of the Falungong affair, which in his opinion was dealt with clumsily by the government.

Wang Lixiong also relies on the impact attributed by some to Yellow Peril in the West: the novel is said to have led to a change in attitude in the West towards the CCP. Wang says he is ready to work more closely with the CCP. He is convinced that China is on the edge of a precipice, and he will stop at nothing to prevent it falling over. His aim is not to come to the rescue of the CCP which is, he asserts, the major cause of the present situation. Wang Lixiong believes that the best solution would be for the CCP to reform itself, which, as he recognises, is unlikely to happen. He concludes Memories of Xinjiang in these terms: "Thinking over what happened to me in Xinjiang, time and distance allow me now to transcend the inital feelings and suffering, and I am beginning to realise the depth of what I gained from it. This led me to reflect deep inside in the course of this struggle for dignity, which made possible the rejection of dependence on 
the government to become consciousness; I was able to experience the feelings of the national minorities by putting myself in their place, and sweep away once and for all the last vestiges of nationalism which remained in me; I understood by personal experience the weakness of human nature, and I have since become all the more tolerant of fear and submissiveness and I abhor autocratic tyranny twice as much. Having walked the frontier between life and death makes it possible for me to adapt to any situation; the courage I begged God to give me then, has since penetrated my soul, silently, like the rain which makes the earth fruitful. I do not believe that I will never again show weakness, but I will certainly be less subject to fear, I will be stronger, I will go out to meet the evil whose arrogance threatens our world, with a more courageous attitude".

Wang Lixiong's intentions appear clearly here. Recounting what happened to him in Xinjiang was necessary in order to carry out his mission as an intellectual-both man of letters and hero-concerned to work for the good of the people, at the risk of lacking in modesty in the role of saviour of humanity.

The heroism of the man of letters

A study of Memories of Xinjiang shows both Wang Lixiong's working methods and the limits imposed by the political environment characteristic of mainland China. Wang is highly critical of the Chinese government and of the CCP. How is it that his activities are nonetheless tolerated? Another contemporary Chinese intellectual, Liu Xiaobo ${ }^{18}$, explains in an article entiled "China: the grey areas of freedom" that censorship is far from having disappeared in mainland China. He points to several websites which have been closed out of hand, among them the one masterminded by Wang Lixiong. For all that, Liu continues, today's China is no longer that of Mao, and peremptory revolutionary statements are no longer sufficient to justify a condemnation. With the opening up of the economy, the Chinese leadership has to make efforts to be appealing in order to attract Western investors and are obliged to behave in a more subtle manner. The new ways of bringing pressure to bear take the form of threats of dismissal for those who have a more or less official job, the suspension of certain classes for those who teach, a ban on publishing, etc. However Liu Xiaobo observes that once they have reached a certain level of renown, intellectuals can generally allow themselves a margin of criticism of the government, as long as it is not a direct and personal attack. In Liu's eyes, the present government's priority is economic growth, and the obsession with profit has weakened the administrative structures all the way up to the censorship organs, whose laxity is evident. Rather than a liberalisation, the grey areas of freedom are the symptoms of profound decay.

This analysis sheds light on the case of Wang Lixiong. Censorship exists, but Wang Lixiong nonetheless finds ways to express himself. His situation is precarious: his website was closed down for some time, his books are not published in China, he was imprisoned for a month in Xinjiang, and forced to resign from Ziran zhi you. But Wang Lixiong is careful not to go beyond certain boundaries. While he questions the legitimacy of a government which he constantly describes as "autocratic", his activity is not directly subversive, he is even ready to collaborate as a zhinang with the government, should it be necessary. Wang does not attack anyone in particular, he merely points to the political errors of the CCP. He starts debates, but he could not be described as a political activist. Moreover he is not a threat to Peking inasmuch as, although he addresses a fairly wide audience, he does not have any powerful means of 
influence. The number of articles available on his website is indeed impressive. However his audience is probably limited to those who are interested in specific problems, and are mostly resident abroad. Lastly, in contrast to other professional intellectuals, Wang Lixiong does not have any official or semi-official post. This unquestionably leaves him greater freedom, for his independence reduces the possibilites for pressure to be brought to bear on him. Despite the virtually total lack of translations of his work, Wang Lixiong enjoys a certain prestige abroad, mostly thanks to the overseas Chinese. This aura does of course have a protective effect. When he was imprisoned in Xinjiang, the protests from abroad very probably had an impact. It is probably more to Peking's advantage to attract the favours of the West than to persecute a spoilsport when he knows how to lie low. Nevertheless, the "freedom" enjoyed by Wang Lixiong remains precarious and highly relative.

Wang Lixiong's intellectual work is original. In Memories of Xinjiang, he judiciously analyses Peking's policy in Xinjiang. His methods, however, are atypical. Firstly he does not have the profile of a dissident. Despite the difficulties he encounters, and the opportunities he has to travel abroad, Wang carries on his activities within China itself. Nor does he seek to overthrow the government, or impose Western-style democracy, which he does not seem to consider applicable to the realities in China. Wang even declares that he is ready to collaborate with the government. He merely wishes that the power of the CCP would dissolve itself, which after all corresponds to the objectives of Communism, which is supposed to lead to the disappearance of the state.

Secondly, Wang Lixiong does not fit the profile of the reforming intellectual within the Party or inside the system. The criticisms he aims at the government are virulent, and he strongly emphasises his quality as an independent intellectual. He is neither a researcher in an institute, nor a journalist, nor a professor in a university, and thus neither "official" nor "semi-official". He relies only on himself and his connections, and carefully avoids any "immoral" collaboration with the government.

Thirdly, Wang Lixiong differs from many intellectuals in the fact that his intellectual work does not make any claims to scientific rigour. It would be tempting to compare Wang Lixiong's case with that of Liu Xiaobo and other "liberal" intellectuals, who are neither dissidents nor reformers within the system, but this proves impossible. Liu Xiaobo, a former professor of philosophy ${ }^{19}$, refers to Western philosophers such as Nietzsche, to question the meaning of Chinese modernity. Wang Lixiong's preoccupations are much more concrete. When he analyses Peking's policy in Xinjiang, Wang quotes some statistical data, and a few leader's phrases, but goes no further in terms of references. Wang Lixiong does not base himself on publications in political science or in ethnology, but goes out in the field and relies on his impressions. The same can be observed in the political system which Wang Lixiong conceives. This is Utopian, in the best sense of the word, because it seems unrealisable and because it is a question of an imaginary ideal government. In Memories of Xinjiang the subject is "the humanist spirit", which he sees as lacking in technocratic officials. To Wang Lixiong, the humanist spirit comes before scientific rigour.

As well as these three observations which give Wang Lixiong's intellectual work its atypcical character, one must emphasise the heroic conception he has of his own role as a man of letters. This already appears in Yellow Peril, a work of the author's early period, but it is still apparent in a later work such as Memories of Xinjiang. The heroism of the man of letters is one of the fundamental characteristics of the literature which 
sprang from the May 4th movement, as Ezra Vogel points out ${ }^{20}$. This heroism of Wang Lixiong's is paradoxical. On the one hand, Wang's aspirations to the function of zhinang show him in a pretentious light; on the other, the archaic character of his heroic attitude make him seem like an amateur. Despite this, Wang subtly analyses the problems of contemporary China and asks judicious questions. He recounts this in an agreeable manner which is accessible to a wide audience, thus carrying the debate beyond the overly narrow circle of specialists. Therein lies his greatest quality.

\section{NOTES}

1. See www.dijin-democracy.net

2. Bao Mi, Huanghuo, Fengyun shidai chuban, Taipei, 1991; can be downloaded at www8800.8800.org/book/wh/hh.html.

3. See www.fon.org.cn.

4. Wang Lixiong, Tianzang: Xizang de mingyun, Mingjing chubanshe, Hong Kong, 1998; can be downloaded at http://members.lycos.co.uk/chinatown/Theme/China/ nation.htm.

5. Wang Lixiong resigned from the Association in May 2001. In his statement he said: "[...] It is no longer acquiescence which is demanded, but the annihilation of the whole personality, of all conscience and of all individual pride, in order to make crouching dogs of us. To continue to belong to this organisation is not an honour, it is on the contrary the shame of any writer worthy of the name". Cf. Chen Yan, L'Eveil de la Chine, La Tour d'Aigues, L'Aube, 2002, p. 287

6. Zhinang, literally "bag of wisdom", a term which traditionally designates a man of resources, who puts his knowledge at the disposal of the government, an "advisor to the Prince".

7. See Liu Xiaobo, "Chine: les zones grises de la liberté", Politique internationale, No 96, 2002, p. 331.

8. See the Human Rights Watch Report, 2003. It states that Wang Lixiong was forced to resign from the organisation, which would otherwise run the risk of having its right to operate withdrawn.

9. See www.future-china.org.tw/fcn/pr/wlx.htm

10. See the supplement of Courrier International No. 629, Nov. 2002. The article was first published in the Peking journal Zhanlüe yu guanli; disgusted with the cuts made in the original text, Wang Lixiong put the whole text on the Internet. The British journal New Left Review translated and published it.

11. See www.chinasite.com/content/Politics/XinjiangStory.htm

12. According to an article in the People's Daily on May 26th 2003, the XPCC has 2.4 million members, of whom $90 \%$ are Han, among them 933,000 workers on the job. See http://fpfre.peopledaily.com.cn/200305/26/fre20030526_61165.html 13. "Open up the West" (Xibu da kaifa) is a government development action programme aimed at stimulating the economy of the mainland regions in order to 
reduce the prosperity and industrialisation differentials between the coastal regions in the East and the inland regions in the West.

14. In modern Chinese two different words are translated as "nationalism". Here Wang Lixiong uses minzu zhuyi, from minzu, the nation or the people, which can be translated as "ethnic nationalism". Further on in the text Wang Lixiong uses the word guojia zhuyi, from guojia, the state, which we could translate as "state nationalism". In the case of the USSR, the two words referred respectively to Russian nationalism and to Soviet nationalism. Marie-Claude Bergère reminds us that the origins of Chinese nationalism are linked to the anti-Manchu movements: China had to free itself from the yoke of the barbarians and become Chinese once again, which implies that the Manchus were not really Chinese and that Chinese nationalism is a Han ethnic nationalism. See Marie-Claire Bergère, Sun Yat-sen, Fayard, Paris, 1994, pp. 178-84. These problems of linguistic ambiguity make it possible to understand more clearly Wang Lixiong's thoughts on the impact of nationalism in Xinjiang. The concept of a "Chinese nation"in Chinese Zhonghua minzu-is all the more ambiguous.

15. Renwen jingshen, "the spirit of culture and of man", a concept which appeared in Chinese intellectual circles in the 1990s, and was the object of lively debate between 1993 and 1995. Chen Yan speaks of a Chinese humanist spirit which is in opposition both to religion-or official ideology-and to the "ordinary", not to say immoral spirit, which is the essence of the market economy. See Chen Yan, L'Eveil de la Chine, op. cit., p. 144. Zhang Lun speaks of a concept which has never been clearly defined, but which refers to the idea of spirituality, metaphysical thought and an interest in culture. See Zhang Lun, La Vie intellectuelle en Chine depuis la mort de Mao, Fayard, Paris, 2003, p. 235. 16. This time Wang Lixiong is speaking of guojia zhuyi, see note 14 .

17. At least according to rumour. See an article in the China Times of Taipei at http:// www.rolandli.com/goods/wlx/wlx.htm. Wang Lixiong's father, Wang Shaolin, was a fellow student of Jiang Zemin's and was his superior in the 1950s. The two families are said to be quite close. Wang Shaolin was persecuted to death during the Cultural Revolution.

18. Former professor of philosophy at the University of Peking. An active member of the Democratic Movement in 1989, he was sentenced to three years of reeducation by labour in 1996, for having called for the self-determination of Tibet. Released on October 7th 1999, he still lives in Peking and publishes on the Internet, as well as in various journals in Hong Kong and in the Chinese diaspora. See Liu Xiaobo, "Chine : les zones grises de la liberté", in Politique internationale, No 96, 2002, pp. 331-47.

19. For a complete study of Liu Xiaobo's intellectual output, see Jens Damm, Liu XiaoboEin moderner Ikonoklast in der Tradition des Vierten-Mai, M.A. dissertation in Sinology, University of Treviso, 1994: http://userpage.fu-berlin.de/ jensdamm/pdf/mag.pdf. 20. See Ezra F. Vogel, "The Unlikely Heroes: The Social Role of the May Fourth Writers", in Merle Goldman ed., Modern Chinese Literature in the May Fourth Era, Harvard University Press, Cambridge (USA) and London, 1977, pp. 145-59. 
INDEX

Thèmes : politique 